\title{
Skal vi have reklame-TV i Danmark?
}

\section{Af Ole Prehn}

\begin{abstract}
Under stor stăhej fik vi rekzamer $i$ 1987 (TV-Syd) og aret efter kom turen tiz nesten resten af Danmark.

Seertaltene lever endnu ikke op til lovens forudsctninger, og reklameselskabet (TVR) har derfor blandet sig uhprt kraftigt $i$ den offentlige debat om reklamernes placering og programlegningen. Dette stemmer ikke scenitg godt med de vandtette skodder mellem reklamer og programlagning, som politikerne havde lovet os. Hvilke yderizgere loftebrud er nodvendige $i$ fremitien, hvis vi skal have TV betatt via reklamer?

ole Prehn gennemgar de politiske forudsetninger, beregninger af de sakaldte kontaktpriser for TV-reklame og seertallene. Han nar frem tit, at reklamestrukturen i TV langt fra har naet sit endelige udviklingsstade i Danmark.

$V i$ har endnu reklame-IV tit gode.
\end{abstract}

\section{Indledning}

Beslutningsprocessen omkring TV2 tog mere end $18 \mathrm{ar}$. Debatten har bolget frem og tilbage ower folgende temaer: Reklamer eller ej? Selvstæandig institution uden for Danmarks Radio? Har vi råd til det? Og endelig i de sidste 3-4 år for etableringen: Hvor skal TV2 placeres? Skal vi have regionalt TV? Og skal stationen selv producere alle sine programmer eller købe hovedparten hos uafhangige selskaber (entreprisemodelien)?

Den 1. oktober 1988 fik vi TV2 1 skæret af en ophedet pressedækning. Debatten drejede sig de forste månedex isar om nyhedernes placering og de asbenlyse problemex, TV2 havde med at tiltrakke det forventede antal seere. Efter at nyhederne blev flyttet til k1. 19 og afkortet, salledes at mange kunne se den anden reklameblok, inden DRs TV-Avisen garr i luften k1. 19.30, er seertallet til reklamerne oget. Men stadigvæk står der et ubesvaret spørgsmå 1 
tilbage: Hvorfor har forventningerne til 'TV2"g gennemslag varet sa store, og er TV2 i virkeligheden den fiasko, mange pastar? Ved at kigge pa beslutningsprocessen, vil man bl.a. se, at forventningerne til seertallene af politisk-taktiske grunde var sat urealistisk hojt.

\section{Mediekomissionens overve telsex}

Det 18 med etableringen af Mediekomissionen i 1981 klart, at en af kommissionens vasentligste opgaver ville vare at skabe grundlag for at oprette et TV2 i Danmark. Der er da heller ikke slinger 1 valsen $i$ komissionens betankning, idet alle dens medlemmer kunne stette, at man ogede det danske tv-udbud med endnu en landsdækkende kana 1. Derimod var man langt fra enige om, hvordan dette skulle ske.

Kommigsionens medlemmer delte $\$ i g i$ en lang rakke mindretal med hensyn til organisation og finansiering, men med den regering, komissionen afleverede sin betankning til, la det klart, at alle politiske bestrabelser ville blive sat ind pa at skabe TV2 som et reklamefinansieret selskab uden for Danmarks Radio.

Man finder derfor ogsa i betankningen en rakke indledende beregninger over, hvordan en sdan reklamefinansiering ville kunne hange sammen. Disse beregninger fremstilles 1 et selvstandigt afsnit, hvor de mulige indtagter ved reklamefinansiexing gennemgås. Men forudsatningen for, at kommissionens regnestykker holder, skal findes et andet sted 1 betwnkningen, hvor det anfores, at en ny tv-kanal naturligvis skal have en vis mindste-sendetid for overhovedet at udgore et alternativ for seerne - og forst da bliver den attraktiv som reklamemedium. Kommisionen skonner, at en ny kanal skal sende mindst omkring 5 timer om dagen for at na dette mal. Det er samtidig denne sendevolumen, der danner basis for komissionens beregninger over omkostningerne ved drift af den nye kanal.

Kommisionen skenner således, at et TV2, der arligt sender 1.500 timers landsprogrammer vil koste ca. $530 \mathrm{mio}$. $\mathrm{kr}$. arligt 1 drift. skal man dertil lagge eventuelle regionale stationer,regnex komissionen med at den ârlige drift vil stige til ca. 620 mio. 
kr., hvis der etableres 3 regionale selskaber med hver 100 timers sendetid. (Betankning $987, \mathrm{p} .87$ )

Tallene bygger angiveligt pos beregninger udfort at Danmarks Radio, og det bemarkes, at en del af kommissionens medlemmex finder, at udgifterne ligger i overkanten af, hvad man vil kunne drive en ny tv-station for. Ser vi pa komissionens sken over mulige indtagter ved salg af reklametid, viser det sig, at der ikke ifølge kommissionens er grundlag for at fuldfinansiere den nye kanal med reklamer. Kommissionen foretager en rakke modelberegninger, hvor variablene dels ex den sakaldte kontakt pris (prisen pr. 1000 seere 130 sekunder) og dels reklamestrukturen. (Betankning 986, p.102)

Forudsatter man en kontaktpris pa $60 \mathrm{kr}$. (hvad kommissionen skenner er den hojst mulige pris) og 20 minutters reklamer bragt i labet af hele aftenfladen, skulle dette kunne indbringe omkring 480 mio. kx. Falder kontaktprisen til $45 \mathrm{kr}$. mindskes indtagten tilsvarende til 361 mio. kr. Forudsatter man i stedet, at der kun ma bringes reklamer mellem k1. 18-19.30 - men stadig vak 20 minutter $i$ alt fordelt 14 blokke - vil indtagten ved en kontaktpris pa $60 \mathrm{kr}$. blive pa $252 \mathrm{mio}$. kr. (ved en kontaktpris pa 45 kr. vil den svinde ind til knap 190 mio. kr.).

Endelig beregner man en mellemlesning, hvor de 20 minutters reklamer bringes mellem $\mathrm{kl} .18 \mathrm{og} 20.05$. Indtagten $\mathrm{vil}$ da svinge mellem 329 - 246 mio. $\mathrm{kr}$. afhangig af kontaktpris. Grundlaget for beregninger er naturligvis, at der er tilstrakkeligt med seere til reklamerne. Kommissionen forudsatter her, at det laveste tal ex 350.000 seere, mens det storste seertal ex pa 775.000 .

Samenligner man disse indtrgtsoverslag med de beregnede driftsudgifter, er det klart, at komissionen ma bemarke, at man ikke finder en finansiering alene via reklamer realistisk. Skulle man opna en fuld inansiering, ville det enten krave meget hoje kontaktpriser eller mange flere seere.

Det er ikke muligt at se af betankningen, pa hvilken baggrund 
beregningerne er foretaget. Man henviser i betankningen naturligvis til andre landes kontaktpriser, som pa det pågaldende tidspunkt i folge komissionen for de lande, vi kan sammenligne os med, ligger pa omkring $30-40 \mathrm{kr}$. Ud fra kommissionens egne forudsatninger ma en beregnet kontaktpris pa $60 \mathrm{kx}$. derfor $\mathbf{s i g e s}$ at vare et optimistisk skøn, og med denne optimisme vil man alts\& ifølge komissionen maksimalt kunne hente 482 mio. kr. hjem 1 indtzgter, forudsat at der bringes 4 blokke af 5 minutter mellem $k 1$. $19.15-22.00$, og forudsat at hele fladen salges.

Man må derfor konstatere, at komissionen selvom den var åbenlys optimistisk 1 sine beregninger, i sin betankning som helhed advarede politikerne on, at man let kunne komme til at overvurdere indtrgtsmulighederne ved salg af reklametid. Og ingen buxde have denne advarsel bedre $i$ exindring end Mediekomissionens formand H.P. Clausen, som blev den minister, der forte forslaget om et delvist reklamefinansieret TV2 igennem folketinget til vedtagelse.

\section{Loven om TV2 - okonomisk set}

Loven om TV2 blev vedtaget i folketinget den 30. maj 1986. Til det sidste habede oppositionen ( $S$ og $S F$ ) at kunne overtale de radikale medlemmer til ikke at stemme for forslaget. Det blev imidlertid vedtaget med 73 stemmer for, 71 imod, mens 3 radikale undlod at stemme. Man kan derfor sige, at forslaget blve barret igennem af De Frie Demokraters ene mandat (tidligere Fremskridtspartiet) samt det faroske medlem.

Som bekendt indebarer loven, at TV2 oprettes som en selvejende institution, dex pallagges at drive selvstandig programvirksomhed finansieret gennem licens og reklame. Loven indeberer samtidig, at der oprettes mellem 6-8 regionale selskaber, som sta for en mindre del af sendetiden.

Ser man p\& debatten i folketinget, er det bemaxkelsesvardigt, at taletiden primart blev brugt til overordnede betragtninger om det betimelige $i$ at indfore reklamefinansieret tv 1 Danmark, mens de mere teknisk-økonomiske forhold, som senere skulle komme til at dominere debatten, kun blev kortfattet berort. 
Det var kun socialdemokratiets ordforer, som forsegte at fastholde regeringen pa de okonomiske spargsmål, idet denne havdede, at lovforslagets kortfattede økonomiske overslag var tvivlsomt. Han mente, sammen med SF, at de opstillede indtagtsmål ikke ville kunne nås med den foreslâede reklamestruktur og de estimerede seertal, og begge partier tilkendegav, at man sa forslaget som et uholdbaxt kompromis for at fa de radikale med. Man forudsa derfor, at det hurtigt ville vise sig nødvendigt at oge andelen af reklametid samt opblode den blokstruktur, som forslaget indebar.

Dette blev afvist af de radikales ordforer samt af kulturminister H.P. Clausen, som beggede havdede, at forslagets beregninger nok skulle vise sig at holde stik. Men nogen egentig argumentation blev ikke anfort. Lovforslaget som vedtaget tager udgangspunkt 1 , at TV2 1 den forste pexiode ska1 sende 850 timer om arret pa landsfladen, mens de regionale stationer hver i deres område skal st: for 150 timer om aret. Sigtemalet er, at TV2 1 lobet af en årrakke skal nå op på omkring 1500 sendetimer on året. Sendefladen er således 1 sit udgangspunkt mindre end det, Mediekommissionen ans\& for et minimum, hvis kanalen skulle kunne tiltrakke et tilstrakkeligt antal seere.

De forste okonomiske overslag fra kultuministeriets side fremlagges $i$ et notat i Januar 1986 (Ministeriet for kulturelle Anliggender: skønnet finansiexingsbehov for TV-2), hvor man arbejdede pa det lovforslag, som skulle aflese et aldre forslag fra 1984, der ikke kunne monstre et flertal pa grund af de radikales modstand. Notatet er sparsont $i$ sin argumentation, idet der alene henvises til "beregninger fra Handelshojskolen i Kobenhavn". Det havdes i notatet, at man med en reklametid pa 15 minutter fordelt i 3 blokke -en for de regionale udsendelser, en for TV2's nyhedsudsendelse og en efter - vil kunne opns en indtagt pa $400 \mathrm{mio}$. $\mathrm{kr}$.

I dette overslag indgár lkke søndage. Tages disse med, anfører notatet, at indtagterne da vil stige til 475 mio. kr. Dette er lidt over det nødvendige grundlag, som ifølge notatet ex 435 mio. kr. af et samlet driftsbudget pa 535 mio. kr. Resten forudsattes dakket gennem en forhojelse af Ilcensen. Notatet navner imidlertid 
Intet om hverken seertal ellex kontaktpriser,og det må konstateres, at dette ikke udgjorde noget realistisk beslutningsgrundlag, Det glorde hellex ikke statsministex poul schliters lofte om, at man kunne hente mellem 3-400 mio. kr. hjem i reklameindtagter, samtidig med at man satte kontaktpriserne "kunstigt" lavt af hen syn til mindre og mellemstore danske virksomheder.

I det endelige lovforslag er de okonomiske overslag udbygget en smule, idet de nu indeholder en angiven kontaktpris samt estimerede seertal. Lovforslagets sken over indtagtsmuligheder byggex p̊̊ beregninger foretaget af Danake Reklamebureauers Brancheforening (ct. tabel 1 ).

\section{Tabel 1}

Skon over indragtsmuligheder ved 15 minulier TV reklome pr. dag

Beregningseksempel. Der er ikke ved beregningen foregrebet stillingtagen til de endelige sendetidspunkter.

\begin{tabular}{|c|c|c|c|c|c|c|c|c|c|c|}
\hline \multirow{3}{*}{$\begin{array}{l}\text { Sendetid for } \\
\text { reklameblokke }\end{array}$} & \multirow{3}{*}{$\begin{array}{l}\text { Gnsn. } \\
\text { pntal } \\
\text { seere } \\
\text { (1000) }\end{array}$} & \multirow{3}{*}{$\begin{array}{c}\text { Pris } \\
\text { pr. } \\
30 \text { sek } \\
\text { spot } \\
(1000 \\
\text { kr.) }\end{array}$} & \multirow{3}{*}{$\begin{array}{l}\text { Autal } \\
\text { spot } \\
\text { pr. } \\
\text { das }\end{array}$} & \multicolumn{3}{|c|}{$\begin{array}{l}\text { TV-reklameforbrug } \\
\text { (= bruttoomsetring }\end{array}$} & \multicolumn{3}{|c|}{ Salgsomkostringer } & \multirow{3}{*}{$\begin{array}{c}\begin{array}{c}\text { TV- } \\
\text { reklame- } \\
\text { indtogt } \\
\text { (neto* } \\
\text { omsatning) }\end{array} \\
\text { (mill. kr.) }\end{array}$} \\
\hline & & & & \multirow{2}{*}{ 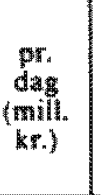 } & \multirow{2}{*}{$\begin{array}{c}\text { pr. } \\
\text { uge } \\
\text { (mill. } \\
\text { kr. })\end{array}$} & \multirow{2}{*}{$\begin{array}{l}\text { pr.sr } \\
\text { (mill. } \\
k r .)\end{array}$} & \multicolumn{2}{|c|}{$\begin{array}{l}\text { Bureau. } \\
\text { provision }\end{array}$} & \multirow{2}{*}{$\begin{array}{c}\begin{array}{c}\text { Faste } \\
\text { on: } \\
\text { kostn. }\end{array} \\
\begin{array}{c}\text { (mill. } \\
\text { kr. })\end{array}\end{array}$} & \\
\hline & & & & & & & $(p c t)$ & $\left(\begin{array}{c}\text { (mill. } \\
\text { ker) }\end{array}\right.$ & & \\
\hline \multicolumn{11}{|l|}{ Mand-morsd. } \\
\hline $19.25-19.30 \ldots$ & 700 & 42 & 10 & 0,420 & 1,680 & 87,360 & 16,5 & 14,414 & & \\
\hline $20.00-20.05 \ldots$ & 1000 & 60 & 10 & 0,600 & 2,4001 & 124,800 & 16.5 & 20.592 & & \\
\hline \multicolumn{11}{|l|}{ Fred.wlord. } \\
\hline $19.25-19.30 \ldots$ & 700 & 42 & 10 & 0.420 & 0,840 & 43,680 & 16,5 & 7.207 & & \\
\hline $20.00-20.05 \ldots$ & 1200 & 72 & 10 & 0,720 & 1.440 & 74,880 & 16,5 & 12.355 & & \\
\hline \multicolumn{11}{|l|}{ Sond. } \\
\hline $18.55-19.00 \ldots$ & 400 & 24 & 10 & 0.240 & 0,240 & 12,480 & 20,0 & 2,496 & & \\
\hline $19.25-19.30 \ldots$ & 700 & 42 & 10 & 0.420 & 0,420 & 21,840 & 16.5 & 3,604 & & \\
\hline $20.00-20.05 \ldots$ & 1000 & 60 & 10 & 0,600 & 0.600 & 31,200 & 16,5 & 5,148 & & \\
\hline \multicolumn{2}{|l|}{ 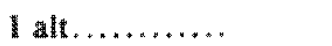 } & & & & & 471,120 & & 80,792 & 15,000 & 375,328 \\
\hline
\end{tabular}

Fondsarninger; (a) 3 reklameblokke à 5 minuter. (b) Regional-TV k1. 19.00-19.25. TV-nyheder k1. 19.30-20.00. (c) Antal seere estimeret pa basis af Danmarks Radios secrundersogelser 1982-1985. (d) Pris pr. 30 sekunder pr. 1000 seere: kr. 60 (kontaktpris).

Kude:

Danske Reklamebureasers Branckeforcning (DR B). 
Af beregningerne fremgåx det, at man med en kontaktpris på 60 $\mathrm{kr}$. (Mediekommissionens hojeste bud og betragteligt over de kontaktpriser, man plejer at sammenligne med for den trykte presse) og med seertal på mellem $400.000-1,2$ mio. vil kunne hente 375 mio. $\mathrm{kr}$. i indtagter til TV2, hvis der dagligt bringes 15 minutters reklame fordelt på 3 blokke placeret før de regionale udsendelser samt for og efter nyhedsudsendelsen.

Det var disse forudsætninger, oppositionen anfægtede under behandlingen af lovforslaget, idet man havdede at specielt seertallene var stærkt overvurderede. Ikke destomindre var det disse beregninger, der blev TV2's finansielle grundlag. Man kan naturligvis altid diskutere, om sådanne beregninger er realistiske, men til syvende og sidst må det komme an på en prøve. Seertallene synes dog, cf. senere, at vare noget optimistiske, idet man har anslâet, at reklameblokken efter nyhedsudsendelsen ville opnå halvdelen af de seer, TV-Avisen havde $i$ den pågældenden periode. Man skønnede altså dels, at TV2 straks ville kunne erobre halvdelen af $t v$-markedet. Denne optimisme kan $i$ det mindste ikke vare hentet fra erfaringer i udlandet, men ma bygge pa formodningen om, at reklame-tv $i$ Danmark beror p\& andre forhold, end man erfaringsvis må basere sig på $i$ andre lande. Denne forventning var ikke destomindre indbygget $i$ forslaget og kom derfor til at dominere de faktiske forventninger til at TV2: hvis de ikke straks exobrede halvdelen af de danske tv-seere, ville de vare en fiasko og komme i økonomiske problemer. Det var til at forudse, at man da faktisk ville fa problemer.

Men den storste svaghed ved forslaget - en svaghed som ikke blev diskuteret under behandlingen - var, at forslaget ikke indeholder forestillinger om,hvordan man skal kunne oge TV2's indtægter i takt med en stigning $i$ programudbuddet og dermed en stigning $i$ driftsudgifterne. Da beregningsgrundlaget som det blev forelagt angiveligt opererer med den maksimalt mulige indtagt under de givne forudsatninger, er det mildest talt uklart, hvor yderligere reklameindtagter skulle komme fra. Eller ogsa er det klart, saledes som hævdet af oppositionen: beregningerne vedrorte alene startfasen, og forslagstillerne matte derfor vare klar over, at 
man $i$ forbindelse med den 1 forslaget beramede revision af loven omkring 1990 ville blive nodt til at andre på reklamestrukturen. Det lykkedes imidlertid ikke at f\& partierne bag forslaget til at indromme dette.

\section{TV2 p\& banen}

1. oktober 1989 lod s\& startskuddet til det danske tw-kapløb mellem TV1 og TV2 - 1 TV2 til Handelsbankens ouverture. Forud for premieren vax gåtet en lang rakke diskussioner om den geografiske placering af den nye kanal og ikke midst placeringen af kanalens nyhedsudsendelse.

stik imod forventningerne (hvis man sex p\& placeringen af reklameblokkene 1 de forskellige beregninger) blev whedeme programsat til k1. 19.30-20.10. Det gik alts ikke, som Helge Sander fra venstre forventede. Han sagde saledes under lovforslagets farstebehandling, at:

... det er da oplagt(...) at det jo ikke bliver saledes, at man sender TV-Avis og TV2's nyhedsavis på samme tidspunkt.

TV2 lagde alts konfrontativt hardt ud med en parallel programlagning p\& nyhedsområdet. TV2 skulle 1 et hug sla den forkatrede TV-Avisen af banen og dermed bade bevise, at TV2 var bedre og anderledes, og foranledige det fornodne seergrundlag for at opna den forventede reklamebaserede indtagt.

Endvidere skal det bemerkes, at TV2's programflade fra starten var af betydeligt storre onfang end de forventede ca. 2,5 timers udsendelser om dagen. Angiveligt var denne disposition begrundet $i$ onsket on at fremst som et reelt alternativ til Dannarks Radio. Kun på denne máde fandt man 1 TV2 at kunne t11trakke det forventede seerantal, som jo qua lovgrundlaget var lagt p\& ca. 50 af seerne - i hvert fald omkring nyhedsudsendelsen. Selvom man forventede, at nyhedsudsendelsen $i$ sig selv ville kunne tiltrakke mange seere, antog man, at hele programfladens tiltrakning og omfang ville vare afgørende for at nâ det onskede mâl. 
Som 1 alle andre lande med reklamefinansieret tv var der stor opmerksomhed omkring seertallene, son efter TV2's start 1 et samarbejde nellem TV2 og Danmarks Radio offentliggores ugentligt. De forste seertal for rv2 var 1 forhold til forventningerne skuffende.Det vigte sig, at dispositionen med at lagge nyhederne parallelt med IV-Avisen ikke var holdbar. I gennemsnit blev Nyhederne kun set af $12 \%$ af de mulige seere $i$ kanalens forste sendeuge. Som det fremgar af tabel 2 (tallene er fra de lobende frekvensundersegelser), var dette tal $i$ uge 51 faldet til et gennemsnit ps 9 .

Tabe1 2

\section{Seertal i procent af muliqe seere}

$\begin{array}{cccc} & \text { Nyhederne } & \text { Reklameblok I } & \text { Reklameblok II } \\ \text { Uge } 40 & 12 & 22 & 15 \\ \text { Uge } 51 & 9 & 16 & 9\end{array}$

Desvarre gik det samne vel med seertallene pl reklameblokkene. Mens det gennemsnitlige seertal til reklameblokkene i uge 40 var pa 18\%, var dette 1 uge 51 faldet t11 13\%. Altsa en klar advarsel om, at udviklingen $g i k$ i den forkerte retning. His man skal sammenligne disse seertal med de 1 lovgrundlaget forudsatte (cf. tabel 1), kan man se, at mallet ikke blev nåt. Seertallene i lovgrundlagets beregninger opererer med en fuld landadakning, mens rv2 naturligvis ikke 1 den forste periode kunne dakke hele landet, da alle sendermaster ikke var rejst.

Beregner man imidlertid seertallet som procent af en fuld dakning, ville seertallene 1 uge 40 svare til, at man nâede 962.000 seere $i$ den forste reklameblok og $655.000 i$ den anden blok. I uge 51 var de tilsvarende tal $700.000 \mathrm{og} 393.000$. Tallene for specielt den anden blok la saledes betragteligt undex de forventede ca. 1 mio. seere. Grunden hertil kunne naturligvis være, at danskerne nar alt kom til alt ikke var sarligt interesserede 1 at se pâ reklamer, og det blev da ogsa hurtigt havdet fra TV-Reklame $\mathbb{A} / \mathrm{S}$, som salger reklametiden, at de lange reklameblokke sa hurtigt efter hinanden var en prohibitiv struktur. 
Men det kunne jo ogsa skyldes, at TV2's programmer ikke kunne tiltrakke et seergrundlag, som kunne smitte af pa reklame-seertallene. Man haftede sig her ved det forhold, at Myhederne Is meget lavt I seertal, og man antog, at dette kunne skyldes sendetiden. Ser man $f . e k s$. på det eneste program, som TV2 $i$ den forste periode havde store seertal på, nemlig Lylkehjulet, viser det sig abenbart, at et attraktivt program efter den sidste reklaneblok kunne bevirke storre seertal på reklamerne.

I uge 51 sa 28 Lykkehjulet om mandagen, og seertallene til reklameblokken forud for programmet var pa 10\%. Om tirsdagen var seertallet til samme program $36 \%$, og seertallene på den forgånde reklameblok var da pa 14\%. Endelig så 30 sykkehjulet om torsdagen, og hex natede reklameblokken for denne udsendelse $12 \%$. Disse tal kan sammenlignes med de andre dage i ugen. Onsdagens program efter den sidste reklameblok tiltrak kun 38 af seerne, og seerprocenten pa reklameblokken var nu faldet t11 6\%. Tilsvarende gjaldt det for fredagens program efter sidste reklameblok, hvor seexprocenten vax pa $9 \%$ og seerprocenten til reklameme forud var tilsvarende lav nemlig 6\%. Eksemplerne illustrerer den banale pointe, at dex er en entydig sammenhang mellem programmernes tiltrakningskraft og seertallene til reklamerne. Pointen ex banal, fordi man erfaringsmasigt ved, at sâdan forholder det sig, nå man drivex reklamefinansieret tv: programlagningen skal søge de mange seere for at t1ltrakke opmarksomhed omkring reklamerne - de kan kun i et mindre omfang gøre det selv.

Men pointen ex ikke mere banal end at man 1 den politiske debat forud for lovvedtagelgen fra forslagetillemes gide mente at have skabt et system, hvor der var vandtatte skodder mellem reklamedeIen og prograndelen. Hvis man havde ret 1 dette, var det netop problemet. Og direktoren for TV-Reklame A/S var da heller ikke sen til at gore opmaxksom pa, at han likke kunne skaffe penge, hvis TV2 ikke kunne skaffe seere. Effekten udeblev ikke, idet der hurtigt viste $\mathrm{sig}$ en tilbageholdenhed 1 bestillinger $t 11$ reklamerne p8 TV2, og resultatet blev, at regeringen annoncerede en hurtigt lovrevision, en revision som bl.a. ogsa skulle omfatte en endelig ordning for finansieringen af lokalutv, som ikke 1 lighed med lokal-radioerne havde mulighed for at bringe reklamer. 
Samtidig viste det sig 1 betydelig grad svart at tegne annoncer til den regionale virksomhed. Man havde specielt problemer med at finde regionale annoncoxer. Troen $p \&$ den regionale blok var derfor 111le, og TV-Reklame A/S advarede om, at hvis lokal-tv fik adgang til at salge reklamer, ville hele grundlaget for de regionale blokke forsvinde, 1igesom lokal-tv antagelig ville tage en bid ogsa af de nationale annoncekroner. Allerede inden TV2 var to måneder gammel Iâ det derfor klart, at der ikke er vandtatte skodder mellem programlagningen og reklamedelen, og det var ogsa klart, at den reklamestruktur, som var indeholdt i loven, ikke på langere sigt var holdbar.

Et vigtigt element i reklamestrukturen var nemlig, at det i grundlaget var fastsat, at reklametiden var ensartet hele sret igennem. Der var derfor ikke mulighed for at bringe flere reklamer 1 "hojsasonen" og farre i "lavsasonen". Dette var et yderligere problem, idet priserne 1 lavsasonen naturligvis ma blive meget mindre end i hojsasonen, hvis man skal kunne fylde reklametiden ud. Denne igen banale tekniske detalje, havde man tilsyneladende overset eller valgt at se bort fra blandt lovgiverne.

Da Julefreden sankede sig over Danmark 1 december 1988 var det med en forvisning om, at skodderne var brudt. Tr2 havde nemlig da annonceret, at man opgav TV2-direktorens prestigeprojekt med parallellitet mellem nyhedsudsendelserne. Nyhedexne skulle flyttes frem til kl. 19,00 og afkortes fra 40 til 30 minutter, og sendetiden efter nyhedsudsendelsen skulle fyldes med bred underholdning for på dêne måde at tage konkurencen op med TV-Aviaen, nar man nu ikke kunne sla dem af banen med nyheder.

\section{Omstart - TV2 o\& banen}

Fra mandag den 2. Januar 1989 lagde TV2 sine programplaner om. Den vasentligste endring var flytningen af kyhederne fra kl. 19.30 til kl. 19.00. Men samtidig betod zendringerne, at der programmassigt på begge tv-kanaler nu satsedes på underholdningsprogrammer 1 den periode, hvor konkurrenten sendte nyheder.

Danmarks Radio lagde 1 perioden $19-19.30$ programmer som Dlck spannex, Muppet show og Ylekuness, mens TV2 $i$ perioden 19.30 og 


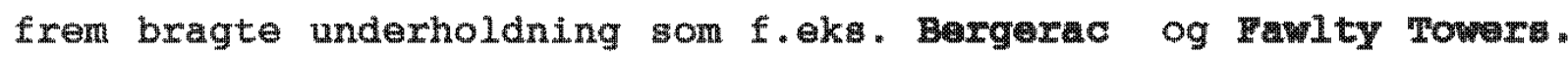
Seerundersøgelserne fra de to forste uger af 1989 synes at vise, at disse andringer har haft en betydelig indflydelse pa seeradfarden - specielt til fordel for TV2. Sammenlignet med tabel 2 viser tabel 3, hvordan seertallene til specielt Nyhedeme nu blev voldsomt foroget.

Tabel 3

Seertal i procent af mulige seere (uge 1 oq 21

$\begin{array}{cccc} & \text { Nuhederne } & \text { Reklameblok I } & \frac{\text { Reklameblok II }}{19} \\ \text { Uge } 1 & 24 & 19 & 15 \\ \text { Uge } 2 & 21 & 17 & 14\end{array}$

Beregner vi igen seertallene $i$ forhold til en totaldakning af landet, betyder dette, at man ville have mellem 750-830.000 seere til den forste reklameblok og 610-655.000 til den anden blok. Interessen for reklamerne ex saledes nogenlunde stabil 1 forhold til udgangspunktet 1 ugerne 40 og 51 i 1988 , men specielt med en klar forbedring $\mathrm{p} \&$ den anden reklameblok. Der ex ikke tvivl om, at specielt forbedringen omkring den anden reklameblok skyldes den meget ogede interesse for at se nyheder på TV2, men også, at programmerne eftex denne reklameblok har gode seertal. Dette giver ugen igennem stabilitet omkring reklameseningen, mens programlagningen 1 efteråret 1988 gav store udsving som angivet ovenfor. Der er sledes nappe tvivl om, at omlagningen af programmerne pa TV2 har varet en gevinst for kanalen og dermed for reklameindtagtsmulighederne. Med de forbehold, man naturligt mâ tage p\& grundlag af kun to undersogelser under de nye forhold, viser det sig, at en del af TV2's succes sker pa bekostning af interessen for Danmarks Radio. Der er altsa ikke tale om, at interessen for TV2 udmontex sig alene 1 et merforbrug af $t v$.

Dette kan illustreres 1 tabel 4, hvor den samlede seertid $i$ en rakke udvalgte uger ex illustreret $i$ antal brugte minutter pr. seer over $13 \mathrm{gr}$. 
Tabel 4

Seertid I minuttex ps kanalerne oq totalt

$\begin{array}{llllcl} & & \text { DR } & \text { TV2 } & \text { ANDRE } & \text { TOTALT } \\ \text { Uge } 40(1988) & 407 & 285 & 57 & 749 \\ \text { Uge } 51(1988) & 381 & 194 & 35 & 610 \\ \text { Uge } 1(1989) & 429 & 402 & 41 & 872 \\ \text { Uge } 2(1989) & 351 & 390 & 36 & 777\end{array}$

I gennemsnit har danskere seere anvendt ca. 90 minutter dagligt p\& dansk tv indtil. TV2 blev etableret, hvilket giver 630 minutter on ugen. Den tid, der bruges til dansk tv nu, nar bortses fra lokal-tv, som er indeholdt $i$ "andre", ex saledes steget. F.eks. sa man i gennemsnit dansk tw i ialt 741 minutter $i$ uge 2 i 1989. Som det ses, Ia TV2 nu en smule over Danmarks Radio 1 forbrugt tid pa programmerne. Seextallene $i$ ugerne efter uge 2 synes at bekrafte, at denne tendens er nogenlunde stabil. Det skal tilfojes, at målingen af den samlede seertid $i$ de offentliggjorte frekvensundersøgelser alene andrager seertiden $i$ den periode, hvor begge kanaler sender. Således vil den reelle seertid på Danmarks Radio vare lidt hojere.

Holder disse tal, betyder det, at TV2 allerede efter f̊ måneder i luften narmer $\mathbf{s i g}$ det niveau, som var forudsat 1 beregningerne. Alt andet lige ma dette siges at vare en prastation. Men som det behandles nedenfor og det ogsa interessant i en okonomisk sammenhang, idet indtagtsgrundlaget dermed nærmer sig sit maksimum, hvis man til grund lagger seertallene.

\section{Ran TV2 lobe rundt?}

Ser man bort fra alle kulturpolitiske betragtninger, som bl.a. kunne pege p\&, at vi med TV2 sex en nasten ikke-eksisterende interesse for "andre", dvs. bl.a. satellitkanalerne, er det interessant at vurdere, hvordan grundlaget for TV2 ser ud - rent okonomisk. Som navnt ovenfor, kan det se ud til, at TV2 har magtet at etablere sig som et seriøst alternativ til Danmarks Radio - kvantitativt set. Man er ude med ret store seertal, ikke 
blot på nyhedsudsendelsen, men også på de ovrige programmer, hvor programomlagningen har betydet en klar forbedring aftenfladen igennem.

Ser vi alene pa reklamedakningen ligger den som sagt omkring $17 \%$ af de mulige seere 1 gennemsnit for de to forste uger af 1989. Hvor meget mere kan man opna? Det ex svart at sige, men sammenligner man de tilsvarende dakningstal med en rakke andre lande, tyder det pa, at man narmer $\mathbf{s i g}$ et maksimum. Dette ex 11 lustreret i tabe1 5. (Kilde: TVR: TV2 fordobler seerta1. 18. januar 1989).

\section{Tabel 5}

\section{Dakningsprocent ved 1 spot-forskellige lande}

$\begin{array}{lr}\text { Holland: } & 13 \\ \text { BRD: } & 9 \\ \text { Finland: } & 24 \\ \text { Schweltz: } & 20 \\ \text { Danmark: } & 17\end{array}$

Exfaringerne tyder alts\& pa, at det er svart at krybe over $20 \%$ af seerne til det enkelte spot. Og det tal ex TV2 nu tat pa. De danske annoncorer kan derfor vare ydexst tilfredse med dakningen p\& reklamerne. Men hvad med priserne? I Mediekormissionens betankning lagde man til grund, at den såkaldte kontaktprisdvs. prisen pr. 1000 seere pa et 30 sekunders spot - bor sammenlignes med de tilsvarende kontaktpriser for den trykte presse.

Dex knytter sig mange problemer til en sadan sammenligning. Det vasentligste problem bestar naturligvis i, hvad "kontakt" overhovedet betyder. Ser man her pa beregningen af kontaktpriser for de trykte mediex, s\& beror de 1 Danmark p\& en sakaldt eksponeringsmulighed. Det vil sige, at man 1 kontaktprisen alene beregner denne ud fra, hvor mange mennesker, der har det pagaldende blad i hånden. Prisen siger ikke i sig selv noget om, hvor mange, der rent faktisk laser den enkelte annonce. Modsat beregnes kontaktprisen ved tv-reklamer pa grundlag af, hvor man seere der faktisk ser annoncerne - eller 1 det mindste påstår at 
have gjort det. Denne mindre usikkerhed kunne tilsige, at tvreklamer alt andet lige kan tillade sig en hojere kontaktpris. Imidlertid ex mallingen af seerfrekvensen på reklamex med den nuvarende metode behæftet ned en del usikkerhed, idet man ikke målex eksponeringen $\mathrm{p} \&$ de enkelte reklamer, men kun eksponering pa den pagaldende reklameblok. Inden for reklamebranchen foretager man mere nejagtige malinger. Disse er dog lkke offentligt tilgangelige. Ved anvendelsen af sakaldte TV-meters, som ogsa planlagges indeført i Danmark, vil man kunne f\& mere nojagtige mallinger.

Endvidere er der et problem i, at kontaktpriser normalt udregnes gennemsnitligt, mens markedsforingen $i$ den trykte presse oftest baserex $\mathrm{sig}$ pa identificerede malgrupper. Det betyder, at en generel kontaktpris ikke er sa interessant, som kontaktprisen for den malgruppe, man er ude efter. Denne reelle kontaktpris, som er mere kompliceret at regne ud, er naturligvis annoncerings massigt den mest interessante. Men det navnes der ikke noget om i Mediekommissionens beregninger.

Ser vi alligevel p\& dette sammenligningsgrundlag viser det $\mathrm{sig}$, at TVR $i$ jeblikket regner med en kontaktpris p\& omkring $90 \mathrm{kr}$. i gennemsnit hen over et $\mathbf{a} r$. Men $i$ lobet af aret er dex naturligvis store udsving p\& grund af sason-problemet. De "tilsvarende" kontaktpriser 1 den trykte presse - dvs. kontaktpriser for en helsides dagbladsannonce ( 1 sort/hvid) og en helsides 4-farvet magasinpresseannonce - ex 1 Dannark på dagbladsomradet pâ mellem 55-80 kx. i de landsdakkende hverdagsaviser, mens de for regionale aviser kan bevage sig op over $200 \mathrm{kr}$. I magasinpressen er kontaktprisen f.eks. i se Hor $35 \mathrm{kr}$. I rodbold r robladet ex den p\& $94 \mathrm{kr} .(1)$.

Dette betyder, at TV2-priserne ligger noget over kontaktprisen for de landsdzkkende aviser, mens kontaktprisen på regionale annoncer typisk vil ligge under dagsbladsprisen. Sporgsmallet ex naturligvis, hvad sadanne tal siger os. For det er jo svart at sammenligne. P\& den ene side kan man sige, at annoncexing $i$ det landsdakkende TV2 sker med en haglbosse, mens man skyder med 
riffel 1 aviserne. Går man til specialaviser og dele af amagsinpressen skyder man her snarere med kikkertsigte. Ps den anden side havdes det ofte, at specielt tv-annoncering har en stor gennemslagskraft, hvilket en del annoncører pa TV2 har kunnet. konstatere $i$ kraft af gget omsætning - hvis deres ord står til troende.

Kan man pa TV2 holde til at have en kontaktpris $i$ overkanten af de med modifikationer sammenlignelige priser $i$ den trykte presse? Ja det afhanger jo naturligvis netop af, on der kan konstateres en salgsmassig effekt af indsatsen. On niveuaet kan holde, er det derfor for tidligt at sige noget om, men det kan dog eksempelvis navnes, at den gennemsnitlige kontaktpris for tv-reklamer i England ligger på omkring $60 \mathrm{kr}$., mens de "tilsvarende" kontaktpriser på dagblade ligger på $40-50 \mathrm{kr}$. og $i$ magasinpressen på 25$30 \mathrm{kr}$. Og i England har man som bekendt haft tv-reklamer siden midten af 1950-erne. Hvis denne relation mellem den trykte presse og tw overføres til Danmark, kan man ikke sige, at TV2's kontaktpriser er for heje.

Ser man endelig p\& tendensen $i$ sjeblikket, viser det sig da også, at interessen for at annoncere 1 TV2 ex s\& stor, at man pa TV-Reklame $\mathrm{A} / \mathrm{S}$ regner med at kunne f\& fyldt pladsen ud. Dette galder i hvert fald på landsannoncerne, mens der måske kan vise sig problemer på de regionale reklameblokke. Interessen for at se disse er noget mindre end pa landsblokkene, men alligevel sa $12 \%$ på reklamerne på TV-Syd 1 uge 2, 1989 - altså på niveau med gennemsnittet for Holland og over gennemsnittet for $B R D$, cf. tabel 5.

Ifølge TV-Reklame $\mathrm{A} / \mathrm{S}$ regner man således optimistisk med at kunne indfri forventningerne, salledes at man skulle kunne aflevere omkring 300 mio. $\mathrm{kr}$. til TV2-fonden i 1989. Dette svarer ikke helt til behovet, men det skal anfores, at denne indtægt 1kke inkluderer eventuelle indtægter fra de regionale blokke. Năr disse ikke ex indregnet skyldes det, at regionerne forst er ved at komme igang. Bortset fra FV-Syd, som har været igang lange, ex det kun TV-FYn, der sender i første kvartal af 1989. Senere 
kommer TV-Mord til $i$ andet kvartal, og senere igen TV-Midt/Vest og TV-Axhua. Som man ser er regionalsenderen $i$ det københavnske område ikke med endnu, selvom det opxindeligt var forudsat, at denne kunne starte med at sende allerede 1 slutningen af 1988. Igangsattelsen af regionalkanalerne ex således forsinket, og ikke mindst forsinkelsen af den økonomisk interessante hovedstadskanal betyder selvfolgelig en mindre indtagt, end man kunne have forventet. Hert 1 komer problemerne med at fa produceret reklamespots 1 de regionale områder. Det har varet et problem bade pa Fyn og i Sønderjylland, at produktionskompetencen vedrorende reklamespota har varet for lille pa de regionale videoselskaber, hvilket hax været medvirkende til en vis tilbageholdenhed hos potentielle regionale annoncorer.

Set $i$ forhold til TV2" driftsbudget for 1989, der ex pa 560 mio. kr., optrader der saledes et rodt tal pa 80 mio. kroner, idet licensen indbringer $180 \mathrm{mio}$. $\mathrm{kr}$. og den forventede reklameindtagt alts 300 mio. Denne manco kunne eventuelt have varet hentet hjem ved en tidligere start af de regionale selskaber. Til gengald spares der en del 1 udgifter af samme arsag, idet man har beregnet hver region $t i 1$ at koste 25 mio. kr. on arret. Alt i alt ser det alts ud t11, at TV2 for sa vidt 1989 kan lobe rundtmed lodder og trisser, men hvordan ser fremtiden ud?

\section{TV2 som reklame-TV i fremtiden}

Son udgangspunkt for at vurdere TV2's fremtidsmuligheder, ma vi forst se pa kanalens budgetoverslag. Disse viser, at man med en gradvis udvidelse af sendetiden til i alt 1.500 timer $i$ 1991 vil f\& brug for indtagter p\& 1 alt 830 mio $\mathrm{kr}$. 1 dette $\mathrm{ar}$. Selvom en rakke store virksomeder $i$ en undersagelse offentliggjort $i$ Markedeforing $1 / 1989$ viser, at annoncererne er utilfredse med bade seertal og priser, og at samme virksomheder forventer $\mathrm{sig}$ en stigning i seertallene pa reklameblokkene, ma vi fastholde, at der nappe ex meget at hente i ogede seertal pá de eksisterende blokke, cf. oventor. 
Samme undersøgelse viser, at interessen for at reklamere i TV2 i 1989 ex mindre, end den var 1 eftersiret 1988 , Idet kun 34 af virksomhederne tilkendegiver, at de helt sikkert vil annoncere i rv2, mens 748 annoncerede 1 1988. Alligevel viser undersogelsen samlet en stor interesse for atermedierne som reklamekanaler, og IV2's nye seertal kan muligvis gore virksomhederne mildere stemt. Men det skal huskes, at ogning i seertallene primart ligger pa TV2's programmer og kun 1 mindre omfang pa reklamerne. Den ogede interesse indikerer derfor forst og fremest, at der skulle vare en rimelig sikkerhed for, at seertallene til reklameblokkene kan fastholdes.

Ikke destomindre skal TV-Reklame A/S ud og finde et betragteligt storre belob 1 1991, end man kan hente hjem 1 1989. Anslas man, at licensindtagten i 1991 belober sig til $230 \mathrm{mio}$. kr, skal der alts skaffes 600 mio. kr. 1 reklameindtagter. Det er ca, det dobbelte af det belob, man regner med at $f$ ind 1 1989! Da der nappe er de store penge at hente på de eksisterende reklameblokke, ex den eneste losning, at reklamestrukturen laves on, således at der bliver mere tid til reklamer, og at reklamerne kan placeres friere, end det ex tilfaldet $i$ dag. Der vil altså vare behov for at udvide reklametiden $t i 1 \mathrm{ca}$. 30 minutter om dagen, og der vil vare behov for, at reklametiden fastsattes som et ârligt gennemsnit, saledes at der kan bringes flere reklamer i "hojsasonen" og modsat i "lavsasonen".

Skal dette kumne lade sig gore, kraver det samtidig, at sendefladen er tilstrakkelig stor. I rv2's budgetoverslag regnes der med 1.500 timer på den landsdakkende flade, hvilket giver omkring 4 timers sendetid dagligt. I forhold til Mediekomissionens overvejelser ligger dette tal betydeligt under, hvad man her fandt matte vare det minimale, nemlig omkring 5 timer.

Med sendetiden som udgangspunkt mâ det derfor konstateres, at man ligger lige $i$ underkanten af det realistiske, hvis reklamerne ikke skal fylde for meget. Regnex vi med en landssendetid på 1.500 timer, og regnex vi med en gennemsnitlig reklamesendetid pa 3o minutter om dagen, ser man, at reklamesendetiden saledes vil 
udgore omkring 128 af den samlede sendetid. Det namer $\mathrm{sig}$ de 15\%, som f.eks. EF og Europaradet arbejder med som det maksimale, men pa en kort sendetid kan de mange reklamer naturligvis virke Irriterende pa seerne i langden, sâledes at der opstår et psykologisk problem.

Sporgsmalet ex $s \&$, on det overhovedet er realistisk at regne med en indtagt på omkring 600 mio. kr. Ogsa dette kan naturligvis vendes og drejes, men tager man afsat i de internationale sammenligninger, som Mediekomissionen anforte, får man folgende potentiale. Ifølge Mediekommissionen udgor reklameomsatningen til tv 1 en rakke vesteuropeiske lande mellem 5-20: af den samlede reklameomsatning.

Regner vi med, at reklameomsatningen 1 Danmark 1 ojeblikket er pa omkring $10 \mathrm{mia}$. $\mathrm{kr}$, giver dette en sprendvidden pa mellem 0,5-

2 mia. kr. Herfra skal trakkes udgifter t11 bureauprovision og produktion. Satter vi disse omkostninger til 25\%, nas vi en beløbsstørrelse på mellem 375 mio. og 1,5 mia. kr. Det betyder, at TV2 skal hente omkring 8-108 af den samlede reklameomsatning 1 Danmark. Dette burde ikke forekomme urealistisk, men det forudsatter som sagt, at reklamestrukturen andres dramatisk, og at TV2 kan fastholde sine seere. Man 1 denne forbindelse sammenligne med, hvor stor en del, WV-reklameomsatningen udger af det samlede reklamebudget $\perp$ andre lande. Ifølge EBU-Review (nov. 1988, p. 30 ) var TV-reklamens andel af det samlede reklamebudget 1 rtalien 48*, BRD: 12\%, Frankrig: 25 \% og USA: $13 \%$.

\section{Skal vi have reklame-TV i Danmark?}

Son det fremgar, havde skeptikerne ret. Forudsatningerne for loven om TV2 holder ikke. Regeringen og dens embedsmand har ikke gjort deres hjemmearbejde godt nok, eller ogs\& har man splilet ud med et kompromisforslag, som kunne f om en kort og koncentreret reklameblok-struktur, som skulle befinde $\mathrm{sig}$ bag vand- og krone-tatte skodder. 
Der ex tre afgerende forhold, som var problematiske 1 lovgrundlaget. For det frrste overvurderede man seertallene, idet man forudsa op mod en million seere til den sidste reklameblok. Dette ma have varet mod bedre viden, for ser man pa seerundersøgelserne fra Danmarks Radio i den periode, hvor beregningerne blev udfort, viser disse klart, at seertallet normalt falder straks efter TVAvisen. Denne har nornmalt haft godt 2 mio. seere, men allerede det naste program har haft betydeligt farre seere - gerne onkring en million mindre, hvis det ikke lige var The coaby show. Det har derfor varet en urimelig hypotese, at reklamer i sig selv skulle kunne vare sa attraktive, at de $i$ modsatning til almindelige programmer skulle kunne holde på så mange seere - 1 en konkurrencesituation. For det andet overs man, at der for tv gar sig betragtelige sasonudsving galdende. Ved at fastlagge en rigid reklameblokstruktur, gjorde man det umuligt for TV-Reklame A/S at hente tilstrakkeligt med penge hjem. For det tredje overs man storsindet det problem, at de stipulerede indtægter kun harmonerede med driftsudgifterne 1 det forste sendeas. At TV2 med en nodvendig sendetidsudvidelse ville fa behov for flere indtagter, fremgar ingen steder.

Denne problemstilling er heller ikke direkte berort i det lovforslag, regeringen den 23 . februax 1989 fremsatte. Forslaget ex resultatet af den allerede før TV2's start bebudede andring, som samtidig skulle afklare finansleringsforholdene omkxing lokal-tv. Mens narradioerne allerede fra augugt 1988 fik tilladelse til at bringe reklamer, blev sporgsmalet om reklamer i lokal-tv udsat for at vurdere dette i relation til TV2's indtjeningsmuligheder. Ifolge de beregninger, ministeriet hax ladet vare grundlaget for de politiske beslutninger - primart beregningerne foretaget af reklamebranchen samt Gronholdt Hansen, - ville tilladelse til reklamer i lokal-tv kunne udgere et ret stort indhug i 'TV's maxked, et forhold, der gentagne gange ogsd har varet anfort af TVR.

Det fremlagte lovforslag ex imidlextid yderst moderat, idet man fastholder, at TV2-selskaberne 1 alt kun må bringe 15 minutters reklamer on dagen og højst $10 \%$ af sendetiden. Pa trods af TVR's 
onsker on det modsatte, opretholder lovforslaget forpligtelsen til at bringe 5 minutters reklame $i$ tilknytning til de regionale udsendelser. Den eneste andring på reklameomradet ex derfor, at man ifolge lovforslaget pa den nationale del af programfladen nu ma bryde reklameme op 1 tre blokke. De to blokke skal fortsat ligge omkring nyhedsudsendelsen, mens den tredje kan placeres et andet ated 1 programfladen, men dog kun mellem udsendelserne. Det afgorende er dog, at der ikke 1 medfør af forslaget bliver mulighed for at udvide reklametiden, 1igesom loven stadig pabyder TV2 at bringe 15 minutters reklamer hver dag. Man kan saledes ikke operere med en planlagning, der tager hensyn til sasonsvingningexne. At man fra regeringspartiernes side godt ex klar over, at man ikke har fundet den endelige form fremgar af, at man 1 lovforslaget opretholder en genbehandling af loven i $1990 / 91$.

Man kan derfor slutte, at TV2 under den nuvarende struktur er et ikke ganske mislykket forseg pa at indfore reklame-tv i Danmark. Men reklame-tv er det lkke. Sporgandlet ex derfor, om det sa er reklame-tv, man vil have. Det skal politikerne afgore. Forelobig tyder alt p\&, at seerne har fundet sig godt tilrette med den nye kanal. Og alt tyder pa, at interessen for dansk tv - eller 1 det mindste $\mathrm{tv}$ transmitteret af danske kanaler - helt har overskygget interessen for de satellit-kanaler, man kulturpolitisk har varet s\& bange for skulle udradere den danske kultur og egenart.

Kulturpolitisk har TV2 som supplement til Danmarks Radio varet en succes, selvom TV2 mangler meget i at udgore et dankk alternativ til de udenlandske kanaler. Kun 44 af IV2's programudbud var 1. uge 3, 1989 af dansk eller nordisk oprindelse, og hele 60 af underholdningen kom fra udlandet (ekskl. Norden).(Beregninger foretaget p\& grundlag af kanalernes udsendte programplaner). Dette forhold skal naturligvis rettes op, al den stund TV2 er forpligtet til at bringe mindst 50 dansk og nordisk stof. Men ogs\& dette koster fo penge, flere penge end billige tv-serier fra udlandet. Og det er disse penge, der er forudset til at skulle stimulere de danske produktionsmil jeer. 
Dette ex de kulturpolitiske forudsatninger, men kulturpolitik koster penge. Skal de kulturpolitiske ambitioner gâ hănd i hand med reklamefinansiering, sts $\mathrm{vi}$ alts stadig overfor en dybtgående lovrevision, der gor op med myten om, at man kan finansiere reklame-tv 1 Danmark $p a$ en helt anderledes facon end 1 andre lande. Nogle politikere har måske troet, at det kunne lade sig gore. Andre har vidst, at det ikke var tilfaldet, men har tiet for at lade realiteterne tale. Det har de gjort nu, men ábenbart ikke tilstrakkeligt.

(1): Tallene bygger p\& beregninger ud fra Dansk Media Index, 2. halvarr 1987/1 halvăr 1988 og er venligt stillet til rådighed af Berlingake Annoncecenter.

\section{Referencer}

De anforte seertal bygger p\& oplysninger publiceret 1 Danmarks Radlo, TV2 TV2 Reklame: Seerundersegelae, den 13. oktober 1988 (dakkende $1 . \circ g$, oktober 1988) $\mathbf{f L}$.

Der bygges endvidere primart på følgende kilder:

Bakendtgerelae om vedtagt for 2V2. Lovtidende $A, 1987$, hafte 54, nr. $483, \mathrm{sp} .1653 \mathrm{ft}$.

Folketinget: foxhandlinger. Folketingstidende $1985-86$ (sp. 10329 ff. forste behandling), (sp. $11885 f$. : anden behanding), ( $\mathrm{sp}$.

12525ff.: tredje behandling), samt speclelt betankning ovex

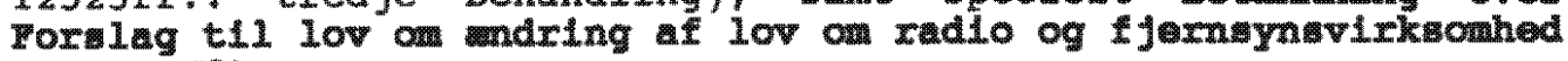
10. (TV2).

For lag til Lov an andring af lov an radlo og fjernsymavirksomhed m.V. (TV2). Lovforslag $n x$. L 245, fremsat den 23. apri1 1986.

Foralag t11 Lov om andring af lov om radiom og fjemeymivirkanhed (Reklame 1 loka1-tv w.v.). Premsat den 23. februar 1989.

Gronholdt, L. $\mathbf{Y}$. Hansen Reklame 1 narradio og lokal-TV. Nogle afstningsokonomiske overvejelser. Handelshojskolen $i$ København, 1987.

Lov on andring af lov om radio- og fjernsynsvirksomhed a. (TV2), Lov nx. 335 af 4 . Juni 1986.

Medlekomistionen: Betankning om et oget dansk tv-udbud. Mediekormissionens betankning nr. 5. Betankning nr. 986.1983. 
Minleteriet for kulturelle AnIlggendex: Skonnet finansieringsbehov for TV-2. 4. kt., j.nx. 0100-3-85. BV/10/032101 not tv-2. 22 . januar 1986.

TVR: TV2 fordobler seerta1. Pressemeddelelse fra TV-Reklame A/S., 18. Januar 1989 .

Der bygges endvidere pa telefonisk indhentede oplysningex fra en lang rakke personer, til hvem der rettes en tak for at have stat til velvillig rådighed.

Endvidere takkes en rakke kolleger for at have taget sig tid til en kritisk gennemlisning af udkast til artiklen.

Ole Prehn ex lektor ved Institut for Kommunikation, Aalborg Univexsitetscenter og medlem af det regionale TV2- selskab TV-Nords bestyrelse. 


\section{Reklamefinansieret lokal-TV som trussel imod TV2?}

\section{Af Frands Mortensen}

I denne artikel undersoges det, om det er muligt at finansiere tokat-IV i Danmark via reklamer, og om en reklamefinansiering af lokal-TV vit udgore en trussel imod TV2's reklameindtegter.

Udgangspunktet for en beregning af de mulige indtegter i lokal-TV er de sakaldte kontaktpriser, dvs. den pris annoncoren betaler for at fa sin reklame vist for 1000 seere $i 30$ sekunder.

Kontaktpriserne for reklamerne $i$ det landsdakkende TV2 kendes nu, og vi har ogsa tal for de regionale reklamer, nemlig dem i TV-Syd og 1 TV-FYn.

Tabel 1: Kontaktpriser i TV 2, TV-Syd og TV-Fyn, oktober 88 - januar 89 (kr.)

$\begin{array}{rrrr}\text { TV 2 } & \text { TV 2 } & & \\ \text { Blok 1 } & \text { Blok2 } & \text { TV-Syd } & \text { TV-Fyn } \\ & & & \\ 73,53 & 115,95 & 43,89 & \\ 83,17 & 168,74 & 46,34 & \\ 69,02 & 123,47 & 63,74 & \\ 67,51 & 77,33 & 28,03 & 24,73\end{array}$

Egne beregninger pá grundlag af AIM's seertal og TVR's prislister. Rabatsalget i TV-Syd er medreget i de lave priser. 